\title{
Analisis Kemampuan Penyelesaian Masalah Geometri Pada Mahasiswa Matematika Universitas Nahdlatul Ulama Blitar
}

\author{
Rachmadania Akbarita ${ }^{(1)}$ \\ ${ }^{1}$ Program Studi Matematika Universitas Nahdlatul Ulama Blitar \\ Email: ${ }^{1}$ dania.barita@gmail.com
}

\section{Tersedia Online di \\ http://www.jurnal.unublitar.ac.id/ index.php/briliant}

\begin{tabular}{l}
\hline Sejarah Artikel \\
\hline Diterima pada 9 Agustus 2018 \\
Disetuji pada 9 Agustus 2018 \\
Dipublikasikan pada 13 Agustus \\
2018 Hal. 345-348 \\
\hline
\end{tabular}

Kata Kunci:

penyelesaian masalah, geometri, matematika, mahasiswa

\section{DOI:}

http://dx.doi.org/10.28926/briliant .v3i3.221

\begin{abstract}
Abstrak: Pembelajaran matematika bagi mahasiswa perlu memperhatikan pengembangan kemampuan penyelesaian masalah (problem solving). Kemampuan penyelesaian masalah berdasarkan Polya terdapat empat tahap, yaitu understanding the problem, devising a plan, carrying out the plan, looking back. Sehingga tujuan dari penelitian ini adalah untuk mengetahui kemampuan penyelesaian masalah geometri pada mahasiswa matematika UNU Blitar.
\end{abstract}

Matematika memegang peranan penting dalam aspek kehidupan manusia. Saat seseorang memiliki dasar pemahaman matematika yang cukup, dalam arti memiliki logika berfikir yang baik, maka dia dapat menyikapi berbagai fenomena dan permasalahan dengan lebih baik. Bagaimana seseorangmerespon sebuah permasalahan yang ditemui setiap hari dengan cepat dan baik, mengambil keputusan secara logis, serta penentuan prioritas dari berbagai pilihan yang ada, hampir semuanya melibatkan kemampuan analisa dan logika matematika. Salah dalam mengambil keputusan, lebih mengutamakan perasaan daripada logika (dalam porsi tertentu), atau salah dalam menentukan prioritas dapat mengakibatkan hasil yang benar-benar berbeda dari yang kita harapkan. Matematika merupakan salah satu materi yang diajarkan pada setiap jenjang pendidikan. Dikarenakan matematika merupakan suatu materi yang terstruktur, terorganisasi, dan berjenjang. Artinya, antara materi yang satu dengan materi yang lainnya saling berkaitan. Dalam pembelajaran matematika, diharapkan mahasiswa dapat melakukan koneksi antar materi yang diajarkan. Salah satu mata pelajaran yang dimaksud adalah matematika.

Sesuai dengan tujuan pembelajaran matematika, yaitu agar siswa memiliki kemampuan: penyelesaian masalah matematis, komunikasi matematis, representasi matematis, koneksi matematis, dan penalaran matematis (NCTM, 2000:7). Kemampuan memecahkan masalah yang dimaksud meliputi kemampuan untuk memahami masalah, merancang model matematika, menyelesaikan model, dan menafsirkan solusi yang diperoleh. Kemampuan untuk memecahkan masalah 
ini sangat penting dimiliki oleh siswa tidak hanya pada materi matematika saja tetapi juga dapat digunakan mahasiswa dalam menyelesaikan masalah yang terjadi dalam kehidupan sehari-hari. Pemecahan masalah dapat mendorong mahasiswa untuk lebih tegar dalam menghadapi berbagai masalah yang ada. Mahasiswa yang terbiasa dihadapkan pada masalah dan berusaha memecahkannya akan memiliki sifat cepat tanggap dan kreatif. Jika masalah yang diciptakan itu berhubungan dengan kebutuhannya maka siswa akan bersemangat untuk memecahkan masalah tersebut dalam waktu yang relatif singkat.

Beberapa ahli menemukan beberaoa cara dalam menyelesaikan masalah matematika, salah satunya adalah Polya. Polya menemukan langkah-langkah yang praktis dan tersusun secara sistematis dalam memecahkan masalah. Dengan adanya langkah-langkah tersebut dapat mempermudah mahasiswa dalam menyelesaikan masalah matematika. Pemecahan masalah menurut Ormrod (2008: 393) adalah menggunakan atau mentransfer pengetahuan dan keterampilan yang sudah ada untuk menjawab pertanyaan yang belum terjawab atau situasi yang lain.

Langkah pertama dalam memecahkan masalah matematika menurut Polya (1973: 5), yaitu understanding the problem atau memahami masalah. Pada langkah ini, siswa harus dapat memahami masalah yang ada dengan cara menetukan dan mencari apa yang diketahui dan apa yang ditanyakan pada masalah tersebut. Langkah kedua yaitu devising a plan atau menyusun rencana pemecahan atau penyelesaiannya. Pada langkah ini, mahasiswa harus dapat menyusun rencana pemecahan atau penyelesaian dari masalah yang ada berdasarkan apa yang telah diketahui dan ditanyakan pada masalah sesuai dengan langkah pertama. Langkah ketiga yaitu carrying out the plan atau menyelesaikan masalah sesuai perencanaan. Pada langkah ini, siswa harus dapat menyelesaikan permasalahan yang ada sesuai dengan perencanaan yang telah dibuat pada langkah kedua. Langkah keempat yaitu looking back atau memeriksa kembali hasil yang telah diperoleh. Pada langkah ini siswa harus dapat memeriksa kembali hasil yang telah diperolehnya, apakah jawabannya sudah benar dan sesuai dengan apa yang ditanyakan pada masalah atau belum. Looking back merupakan langkah terakhir dalam memecahkan masalah matematika berdasarkan langkah-langkah Polya.

Berdasarkan observasi yang dilakukan peneliti, pembelajaran pada mata kuliah geometri pada program studi matematika UNU Blitar telah menggunakan pendekatan konstruktivis yang berpusat pada mahasiswa. Akan tetapi dalam hal hasil pembelajaran, masih jarang terdapat mahasiswa yang mampu menyelesaikan masalah dengan cara ataupun pendekatan berbeda dengan yang diajarkan dosen pengampu. Berdasarkan hasil temuan tersebut, peneliti tertarik untuk menggali lebih dalam lagi mengenai kemampuan berpikir kreatif konsep geometri mahasiswa UNU Blitar. Konsep geometri yang dimaksud adalah geometri bidang datar, yaitu pada materi segitiga dan segiempat yang diajarkan. Pemilihan materi geometri karena geometri sebenarnya merupakan materi matematika yang telah didapat di setiap jenjang pendidikan baik SD, SMP, maupun SMA. Sehingga seharusnya dalam tingkat perguruan tinggi, mahasiswa sudah menguasai materi tersebut. pemahaman Oleh karena itu, tujuan penelitian ini adalah untuk mendeskripsikan kemampuan penyelesaian masalah geometri pada mahasiswa matematika Universitas Nahdlatul Ulama Blitar.

346 BRILIANT: Jurnal Riset dan Konseptual Volume 3 Nomor 3, Februari 2018 


\section{METODE}

Penelitian yang dilakukan merupakan penelitian deskriptif-kualitatif, artinya menggambarkan atau mendeskripsikan kejadian-kejadian yang menjadi pusat perhatian secara kualitatif dan berdasarkan data kualitatif. Subjek penelitian adalah mahasiswa UNU Blitar yang sedang menempuh matakuliah geometri berjumlah 36 mahasiswa. Penelitian ini dilakukan dengan memberikan tes kemampuan pemecahaan masalah pada materi geometri. Data yang didapat adalah data persentase setiap tahap penyelesaian masalah yang akan dikualifikasikan mejadi empat kategori menurut Morris dan Gibbon (1986: 142), yakni tinggi, sedang, rendah, dan sangat rendah.

\section{HASIL}

Dari data skor mahasiswa diperoleh rata-rata persentase skor setiap tahapan penyelesaian tes kemampuan pemecahan masalah yang disajikan dalam tabel berikut:

\section{Tabel 1. Rata-rata Persentase Skor Tahapan Penyelesaian Tes Kemampuan} Penyelesaian Masalah

\begin{tabular}{|l|l|c|c|}
\hline No & \multicolumn{1}{|c|}{ Tahapan Penyelesaian } & $\begin{array}{c}\text { Persentase } \\
(\mathbf{\%})\end{array}$ & Kualifikasi \\
\hline 1 & Understanding the problem & 76 & Tinggi \\
\hline 2 & Devising a plan & 52,4 & Sedang \\
\hline 3 & Carrying out the plan & 13,22 & Sangat rendah \\
\hline 4 & Looking back & 10,15 & Sangat rendah \\
\hline
\end{tabular}

Hasil pada tabel di atas menunjukkan bahwa setiap mahasiswa memiliki kemampuan yang tinggi dalam memahami masalah, akan tetapi sebagian besar mahasiswa belum mampu melanjutkan ke tahap selanjutnya, yaitu menyelesaiakan masalah yang diberikan. Hal ini dapat dilihat dari persentase skor mahasiswa dalam menyelesaikan masalah. Persentase yang diperoleh untuk tahap tersebut adalah 13,22\%, termasuk dalam kualifikasi sangat rendah. Begitu juga dengan tahap terakhir, yaitu tahap pengecekan kembali yang juga memberikan hasil persentase yang masuk dalam kategori sangat rendah.

\section{PEMBAHASAN}

Berdasarkan paparan data pada bab sebelumnya, didapatkan hasil bahwa secara keseluruhan, mahasiswa matematika kurang mempunyai kemampuan menyelesaian masalah. Kebanyakan dari mereka, hanya sampai pada tahap memahami masalah. Hal ini juga ditunjang oleh hasil wawancara kepada beberapa mahasiswa yang telah dipilih. Dari hasil wawancara, terdapat beberapa faktor yang mempengaruhi mahasiswa dalam menyelesaikan masalah yang telah diberikan, salah satunya adalah mereka kurang teliti dalam memahami masalah pada persoalan yang diberikan sehingga mengakibatkan tahapan-tahapan selanjutnya tidak dapat terselesaikan. Faktor lain yang mempengaruhi adalah bahwa mereka tidak mempunyai ide dalam menyelesaikan persoalan tersebut walaupun materinya adalah materi geometri yang telah mahasiswa kenal sejak sekolah dasar. Sehingga mahasiswa hanya menuliskan apa yang diketahui dan apa yang ditanyakan. Dari hasil-hasil tersebut, didapatkan suatu analisis bahwa 
kemungkinan faktor utamanya adalah kurangnya kemampuan berfikir kreatif pada mahasiswa matematika UNU Blitar. Berpikir kreatif merupakan kombinasi berpikir logis dan berpikir divergen yang didasarkan pada intuisi tetapi dalam kesadaran yang memperhatikan keluwesan, kelancaran, dan keaslian (Haylock,1997; Silver, 1997; Pehkonen, 1999; Wahidin, 2009). Hal tersebut, dapat disebabkan oleh banyak faktor yang seharusnya menjadi bahan penelitian lanjutan dari hasil temuan ini.

\section{KESIMPULAN}

Berdasarkan hasil analisis data dan sesuai dengan masalah, tujuan dan hipotesis penulis memiliki kesimpulan bahwa terdapat perbedaan yang signifikan antara prestasi belajar siswa sebelum dan sesudah diberikan demonstrasi dalam mengajar dan belajar topik teks prosedur untuk siswa kelas empat STKIP PGRI Nganjuk pada tahun akademik 2016/2017, nilai rata-rata prestasi belajar siswa sebelum metode demonstrasi yang diberikan adalah 71,81 dan skor mereka setelah diberikan metode demonstrasi adalah 79,86. Ini berarti bahwa setelah metode demonstrasi diterapkan, skor peningkatan kosakata siswa meningkat.

\section{SARAN}

Saran yang dapat disampaikan adalah bahwa sebaiknya diadakan penelitian lanjutan untuk mengetahui faktor-faktor yang menjadi penyebab kemampuan penyelesaian masalah geometri pada mahasiswa matematika UNU Blitar masih tergolong rendah. Sehingga dengan diadakannya penelitianpenelitian tersebut dapat meningkatkan kemampuan penyelesaian masalah matematika pada mahasiswa matematika UNU Blitar di kemudian hari.

\section{DAFTAR RUJUKAN}

Arikunto, Suharsimi. 2001. Dasar-dasar Evaluasi Pendidikan. Jakarta: Bumi Aksara.

Haylock, Derek. 1997. Recognizing mathematics creativity in Schoolchildren. Norwich. Page 68-74.

NCTM. 2000. Principles and Standarts for School Mathematics.NCTM Inc: United States Of America.

Omrod, J. E. 2008. Psikologi Pendidikan (Membantu Siswa Tumbuh dan Berkembang). Penerjemah: Amitya Kumara. Jakarta: Erlangga

Polya, G. 1973. How To Solve It (A New Aspect of Mathematical Method). New Jersey: Priceton University Press.

Silver, E. A. (1997). Fostering Creativity through Instruction Rich in Mathematical Problem Solving and Thinking in Problem Posing. ZDM, 29(3). Electronic Edition ISSN 1615-679X. (online) http://www.fiz.karsruhe.de/fiz/publication/zdm. diakses tanggal 1 November 2017.

Wahidin, Didin. 2009. Berpikir Kreatif. (online) http://didin_un_nus.blogspot.com/2009/03/berpikir_kreatif.html/ diakses tanggal 5 November 2017. 